\title{
LIVONIAN PLACE NAMES: DOCUMENTATION, RESEARCH, PROBLEMS, AND OPPORTUNITIES
}

\author{
Valts Ernštreits \\ University of Latvia
}

\begin{abstract}
Livonian is one of the most endangered languages in Europe. Place names of Livonian origin are found not only where Livonian was recently spoken, but also in territories historically inhabited by Livonians across Latvia. Collection and study of place names in Livonian, however, has been fragmentary and largely occurred as part of other research. Documenting place names through field work is no longer possible, as few Livonian speakers remain and most of them know only already documented place names. This article gives an overview of previous work on research of place names in Livonian and grammatical features of such place names, examines techniques for collecting and reconstructing place names in Livonian using innovative approaches with existing data sources (e.g., harvesting place names from metadata), and explains the need for an authoritative source so Livonian place names can be used on official signage to visually demarcate the Livonian areas of Latvia and restore the Livonian place name landscape.
\end{abstract}

Keywords: place names, onomastics, linguistic landscape, language status, Livonian

DOI: https://doi.org/10.12697/jeful.2020.11.1.09

\section{Introduction}

Livonian, an indigenous language of Latvia, is currently one of the most endangered languages in Europe, but was once spoken across a large part of Latvia. Livonian heritage has a significant, though understudied role, not only in the formation of modern Latvia, but also across the broader Northern European region.

Place names are an important part of Livonian linguistic heritage. In addition to Livonian place names in areas where Livonian was still spoken recently, place names of Livonian origin are also found over a much wider area, which includes a large part of modern-day Latvia and in a few places extends across its current borders. For this reason, the identification and study of place names in Livonian along with 
determining the principles for their derivation and use makes it possible to better understand the use of Livonian place names in other languages as well.

Livonian place names and place names of Livonian origin contain information about the development of Livonian and the Finnic languages as a whole during recent as well as ancient history. A greater understanding of Livonian place names, their derivation principles, and their range is significant to the study of the unique features of Livonian and its speech area, also in the larger context of Finnic and Baltic language contacts.

Currently, both of these aspects are especially significant in Latvia where there is a tendency, in the study of place names of Livonian and Finnic origin, to refer to sources, which are not appropriate or relevant for a given place name's location or historical language contacts. For example, identifying the forms corresponding to a place name of Finnic origin in the modern Finnish or Estonian literary languages, while ignoring the languages and varieties spoken in the place name's actual location, such as Livonian, the dialects of southwestern continental Estonia, various South Estonian varieties - including the Leivu and Lutsi sub-dialects, or the Krevin variety of Votic.

However, this article is devoted to place names in Livonian, therefore the term "Livonian place names" is used here to refer to place names in the Livonian language rather than to the place names of Livonian origin in other languages. Due to the fact that place names in Livonian are studied extremely seldomly, some researchers tend to confuse place names in the Livonian language with place names of Livonian origin, which are not the subject of this article.

This article mainly examines place names in the Courland dialect of Livonian and various other aspects connected with Livonian place names - work carried out thus far in their documentation, study, and publication; current possibilities for collecting place names when this is no longer possible through fieldwork with speakers; the features associated with the derivation and use of place names; as well as the possibilities for maintaining and restoring the Livonian place name landscape. 


\section{The documentation, publication, and study of Livonian place names}

Up to this point, the collection and study of Livonian place names has been rather fragmentary. Quite unexpectedly, at the point when this article had already been submitted for publication, the author received a previously unknown Livonian place name collection (PDK), which had been compiled by Livonian writer and linguist Pētõr Damberg. This collection had been stored by Pētõr Damberg's son Valdis Dambergs and was donated by him to the UL Livonian Institute.

This collection contains several hundred Livonian place names primarily microtoponyms - from the villages of Mustānum (Melnsils), Kūolka (Kolka), Vaid (Vaide), Sänag (Saunags), Pitrõg (Pitrags), Kuoštrõg (Košrags), and Irē (Mazirbe). It contains place names, information about their location and consultants as well as notes and legends about their origin. The precise period in the 1970s when this collection was assembled and the details of its compilation are topics which would likely require further study. However, the content of the collection suggest that it is incomplete, i.e., it omits the western Livonian villages where place name documentation may not have been carried out due to various logistical and other difficulties. However, taking into account the fact that the collection also omits the Livonian place names of Ūžkilā (Jaunciems) village and P. Damberg's native Sīkrõg (Sīkrags) village, it may be that part of the collection has gone missing or that P. Damberg never got around to prepare a section on Sīkrõg, leaving the description of the place names most familiar to him to a later date. Other fieldwork projects with the primary goal of documenting Livonian place names have not been conducted.

The majority of other material on Livonian place names has mainly been acquired as a by-product of studies and fieldwork, which had some other goal for their data collection. Livonian place names have mainly been collected as part of general lexical documentation for various lexicographic publications and their card files (for example, the Livonian-German-Livonian Dictionary $(\mathrm{SjW})$, the Livonian-German Dictionary (LW), the Livonian-Latvian-Esperanto Dictionary (ČDG), which contain place names in Courland Livonian, and the Salaca Livonian Dictionary (SLW), which contains place names in Salaca Livonian). Currently, the largest accessible collection of Livonian place 
names is the Livonian-Estonian-Latvian Dictionary (LELD), which was published in 2012. It contains 185 Livonian place names in its place name section (LELD: 380-381); these include the names of countries, cities, and other geographical objects along with their grammatical information and correspondences in Estonian and Latvian.

Livonian place names, mostly microtoponyms, have been collected during various Estonian ethnologists' expeditions to the Livonians of northern Courland, for example, the 1968, 1969, 1970, and 1976 expeditions of Jüri Linnus, during which artists Mati Ruljand and Lembit Lepp sketched several Livonian village maps that included Livonian microtoponyms. These materials are stored at the Estonian National Museum (Blumberga et al. 2013: 55, 533-535).

There have been several Latvian onomastics expeditions to the northern Courland Livonian speech area (to the eastern Livonian villages in 1962, 1969, 1980, 1986; to the western Livonian villages in 1964, 1985). Several of these also included fragmentary documentation of Livonian place names. It should be noted that Livonian forms are often recorded based on their sound (e.g., Kuolkā nanā 'Cape Kolka' instead of Küolka nanā) and that this was done by researchers with limited Livonian language knowledge or even none at all; therefore, the material from these sources should be treated with caution. The most significant of these collections is the documentation of a Latvian dialectologist Marta Rudzìte in the Livonian villages of Dundaga parish during her 1964 expedition. This documentation occasionally also contains the Livonian forms of the documented place names. The materials from these expeditions are stored in the University of Latvia Latvian Language Institute Place Name Card File (LVK).

In 1992, University of Latvia Department of Geography research fellows Zinta Goba and Jurgis Kavacs carried out extensive collecting and mapping of Livonian Coast place names. They wrote down and mapped approximately 1,500 place names (Sîlis 1996). This collection of Latvian place names in the Livonian region remains unpublished (LR). In addition to the expeditions conducted by various onomasts, local historians such as Ivars Abajs of Dundaga and Valda Šuvcāne of Kolka have also carried out place name collection and mapping in the Livonian language speech area.

In discussing Livonian place name documentation, special attention should be paid to the place names documented in the early 1990s by the 
most significant researcher of Livonian place names - Kersti Boiko. She created this collection for her dissertation on Finnic geographic appellatives in Latvian (Boiko 1993) while excerpting Livonian place name material from the most extensive Livonian lexicographic source at that time - Lauri Kettunen's dictionary (LW; Boiko 1993: 4). This collection also includes the Livonian forms of these place names. In addition to her dissertation, K. Boiko is the author of several articles, which also cover issues connected with Livonian place names (Boiko 1990, 1997).

The situation in general is one where place names were intensively documented in the areas inhabited by Livonians; however, the documentation of place names in Livonian has been meagre and fragmentary. The primary reasons for this are the limited size of the geographical area and - even more importantly - the absence of knowledge of the Livonian language and limited access to Livonian language consultants, which is a problem that has become even more acute now than in the past.

\section{Opportunities for Livonian place name documentation in the present day}

Presently, recording of place names through field work is no longer possible. There remain few Livonian speakers and due to the Livonians' historical situation, their connection with the territories historically inhabited by Livonians is often indirect and their knowledge of Livonian place names is minimal. They may know the Livonian names of the most important geographic landmarks; however, all of these have already been found in earlier sources. Therefore, non-traditional methods must be used for collecting Livonian place names. This involves taking a fresh look at the existing collections of Livonian materials and options for retrieving place names from these sources using indirect methods.

\subsection{Use of sources from other fields for collecting Livonian place names}

In addition to the place name collections mentioned in the previous section, there is another group of sources, which is not a compilation of place names, but can be used for collecting Livonian place names. 
This group includes lexical card files, object card files and descriptions, and folklore collections. The metadata in these collections contain references to the time and method as well as the place where each item was collected. Additionally, in nearly all cases, the place names in these collections are given in their Livonian form and also contain some grammatical information (e.g., use of the place name in different noun cases).

These types of collections include Oskar Loorits's Livonian Ethnographic Term Card File and Livonian Folk Tale Collection (Estonian Literary Museum), Ferdinand Linnus's 1927 and 1928 Livonian expedition diaries and card file (private collection, Estonia), Lauri Kettunen's Livonian lexical card file (Estonian Literary Museum) and Eemil Nestor Setälä's Livonian lexical card file (National Archives of Finland) as well as various other collections. With only a few individual exceptions, Livonian collections in Latvia cannot be used as a source of Livonian place names, as their metadata, including location information, is given in Latvian, not in Livonian. Along with these collections, place name data may also be acquired from the metadata in publications based on these sources (e.g., Loorits 1936; Loorits 1998; Loorits 2000, Setälä 1953, etc.).

Place names collected in this way can be supplemented with the ones gathered from various publications devoted to Livonian topics. However, the most effective version of this approach involves gathering place names from the Livonian texts, while, for example, they are being indexed for the Livonian language corpus. Extensive place name material is available in, for example, the Livonian newspaper "Livvli" (Lìvli) published in 1931-1939 or O. Loorits's Livonian Folk Tale Collection texts (Estonian Literary Museum).

It is also noteworthy that place names, which can be documented in this way, refer to places important in Livonian culture and located on areas historically inhabited by Livonians. These places (for example, homesteads which have disappeared or have been moved, drained rivers or lakes, etc.) are typically not found in any available place name collection or cartographic product.

The UL Livonian Institute has begun the creation of a Livonian place name register (as part of the Fundamental and Applied Research Programme project "Documenting and mapping Livonian place names and creating an official place name register"), which will significantly 
contribute to Livonian place name documentation and study; however, the results of this work will only come in a few years' time. This article also came about as a part of this project and utilises the method described herein.

\subsection{Mapping of Livonian place names}

With respect to the practical utilisation of Livonian place names, including the restoration of the place name landscape discussed in this article as well as benefits for research, it is of fundamental importance not only to collect place names and their forms, but also to connect them with geospatial information. However, here, too, the main problem is the lack of the necessary sources and Livonian language consultants. From existing collections and sources only the aforementioned Livonian village maps are well-suited for this purpose. These maps contain Livonian place names; however, they reflect only a small part of all collected place names as well as those which will be harvested in the future from the metadata associated with collections in different sources.

The situation with Latvian place names and their mapping in the territories historically inhabited by Livonians is considerably better. High-quality cartographic material with mapped Latvian place names including microtoponyms - is available from Jāna sēta Map Publishers Ltd (SIA "Kařšu izdevniecība Jāna sēta") and the Latvian Geospatial Information Agency (LGIA). In addition, Latvian place names of the Livonian Coast - the last territory inhabited by Livonians in northern Courland - have been extensively documented and were assembled in the aforementioned cartographic materials produced in 1992 (LR). Therefore, it is possible to resolve the problems associated with mapping Livonian place names by using geospatial information linked to Latvian place names as an intermediary step for Livonian place name mapping.

In general, the following methods can be used for place name mapping: 1) place name localisation and the correspondence of Livonian and Latvian forms (liC Sūonìtkāngar = lv Sonītkangars); 2) place name localisation and correspondence of the content of the place name (liC Sürmõtsād joug = lv Dižmeža strauts 'Large Forest Stream'); 3) localisation according to the description of the geospatial object in textual sources (the location of the object relative to that of other objects with 
a known localisation; textual material from the Livonian language corpus (for example, the Livonian story collection) and other sources); 4) references within sources to the Latvian place names corresponding to Livonian place names; 5) information from other areas (for example, information on the progress of an expedition from which a particular place name collection was derived, the location of landmarks which have since disappeared, interviews with residents during field work, etc.).

\subsection{Use of mapped Livonian place names}

The collecting and mapping of Livonian place names could lay the groundwork for modern interdisciplinary documentation and research of Livonian heritage in the future conducted from a broader perspective.

A Livonian place name archive created and mapped using the methods described above could serve as a starting point for the creation of database clusters relating to the Livonians, making it possible to connect data from several fields (information on consultants; dialect materials; object, folklore, and oral history collections; and other information, including data from collections and sources used for collecting Livonian place names) using place names found in the metadata of these collections and in the geospatially linked Livonian place name register, thereby opening up new possibilities for the multifaceted documentation and research of the Livonian heritage and language.

Mapped Livonian place names may also serve as a basis for the creation of other derived open-access products in the future, supplementing the mapped place names with data from other fields (registers of cultural and archaeological monuments, geological information, tourist information, etc.). This will permit the creation of digital exhibits utilising cartographic products as well as using these products for educational programmes exploring regional heritage, cultural tourism, entrepreneurship, and many other areas.

\section{Grammatical features of Livonian place names}

In addition to actually documenting a particular place name, it is also important to determine its grammatical features, derivation principles, and how it is used. Not only are collections containing the nominative 
case forms of place names important for achieving this aim, but also those sources, which show how the other grammatical forms of each place name are used. Various Livonian language texts - especially the stories included in O. Loorits's folk tale collection mentioned above as well as other folklore and oral history texts - have a special role in this regard and are well-suited for studying Livonian microtoponyms. Periodicals and similar publications in Livonian (Līvli, RĀ 1932, RĀ1933, LL 1921, LL 1922, LL 1923, LL 1924, LL 1926) as well as correspondence and other contemporary sources, which use inflected forms of place names for locations outside of the Livonian speech area, are useful for identifying the adaptation principles used for place names.

\subsection{Place name use in Livonian}

One of the features of Livonian place names, which requires further study, is the use of external locative cases (allative, adessive, ablative), which have largely disappeared for other lexical units. Traditionally, words which were historically formed using one of these cases are considered to be frozen forms and analysed as adverbs (e.g., aigal 'during (a particular) time', lovāl 'in bed', mó 'jjimizõl 'under the influence of'; LELD), though in certain villages in the Eastern Courland Livonian dialect area (Sīkrags, Košrags, Vaide), systematic use of these noun cases has been observed.

For some place name groups, however, the external cases are used paradigmatically across the entire area where the Eastern Courland Livonian dialect was spoken. The external cases are regularly used with place names which contain the appellative $m \bar{o}$ 'land', for example, liE Sōrmōl ('on Saaremaa Island'; AllSg) and Rūotšmōl 'in Sweden' (AllSg) (LELD); Lețmāld 'from Latvia' (AblSg) (Līvli 1931/1: 3), cf. liW Rūočmās 'in Sweden' (IneSg), Piṇmās 'in Finland' (IneSg), and Ingrõmās 'in Ingermanland' (IneSg) (RĀ 1932: 45).

The external cases are used fairly systematically for the majority of the names of the villages located in the Eastern Courland Livonian dialect area: Pitrõg 'Pitrags': Pitrõgõl (AllSg), Irēe 'Mazirbe': Irēl Irail (AllSg), Vaid 'Vaide': Vaidõl (AllSg), Mustānum 'Melnsils':

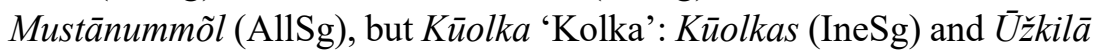
'Jaunciems': Ǔžkilās (IneSg). Eastern Courland Livonian also uses only internal cases for the names of villages located in the Western Courland 
Livonian dialect area: Ira 'Lielirbe': Irras (IneSg), Piza 'Miḳeḷtornis': Pizās (IneSg), Lūž 'Lūžņa': Lüžõo (IneSg) (LELD).

The features of Livonian compound place names should also be clarified - whether the initial component is in the singular (e.g., Siprikšvigā 'Siprikšviga', Tubāmägūd 'Istabkalni') or plural (e.g., Karnõdmä'g 'Vārnu kalns', Sūrmõtsād jo'ug 'Dižmeža strauts'), whether the plural is used in Livonian bog names (e.g., Kanniztsūo 'Pūpoliņu purvs', Nabāld 'Nabalu purvs', Pēmpõd 'Pempi [bog]', Rabādsūo 'Drabiṇpurvs'), and other questions.

The principles for the Livonian versions of place names in Latvia and other countries are also unclear. Much as in Estonian and in Finnish, foreign place names - as long as they do not already have an accepted Livonian form (e.g., Rīgõ 'Rīga', Jālgab 'Jelgava', Lìepõ 'Liepāja', Āpsal 'Haapsalu', Pärnov 'Pärnu', Kinnõmō 'Kihnu', Moskov 'Moscow', Pêtõrburg 'St. Petersburg'; LELD) should be written in their original form according to Livonian orthographic principles, transliterating when necessary (Latvian is mostly used as the source for transliterated place names). However, it can be seen that in the process of creating these place names, some adjustments have been made so that they conform to the Livonian orthography (which lacks certain letters used in Latvian: $c, \check{c}, k, g$ ) as well as to its pronunciation and grammatical principles (e.g., Šveits 'Switzerland', Třsehij 'Czech Republic', Itālij 'Italy', Izrael 'Israel', Japān 'Japan', Kanād 'Canada'; LELD).

The aforementioned examples and also place names like Rumēnij 'Romania' cf. lv Rumānija, ee Rumeenia, Moldov 'Moldova' cf. lv Moldāvija, ee Moldova, Zemgal 'Zemgale', Ladgal 'Latgale' (LELD), also Daugavpil 'Daugavpils', Krustpil 'Krustpils', Gulben 'Gulbene', Plaviñ 'Pḷavinas' (Līvli 1932/3: 1) show a tendency of dropping place name endings, which mark gender in Latvian. This principle has been extended to place names in other languages (e.g., Kuresār 'Kuressaare', Tšehij 'Czech Republic', Itālij 'Italy', Kanād 'Canada') and also place names in Latvia (Kemer 'Kemeri') when creating their Livonianised forms (Livvli 1932/4: 2). Therefore, it is an open and rather topical question what principles should be applied when using place names from other languages in Livonian which have never previously been used in Livonian. Many place names in Latvia also fall into this category. 


\subsection{Features of Livonian place name use in other languages}

The grammatical nuances of place name use are also important when discussing Livonian language, culture, and history in other languages. With the recent burst of activity in Livonian research, the limited use of Livonian place names in the past has raised the question of which language should these place names be used in when discussing Livonian topics. In Latvian, this problem is easy to resolve - all place names either have parallel forms or such forms can be created intuitively. However, in other languages - such as English, Estonian, and Finnish where the accepted practice is to write place names in their original form, it is necessary to choose between using the place name in a form matching the subject matter (i.e., using their original forms in Livonian) or being able to find these place names on maps (i.e., using their parallel forms in Latvian).

In publications, this is mostly resolved by using both place names by either writing the Livonian form first and then writing the Latvian form in parentheses afterwards or vice versa. Due to the close relationship of Finnish and especially Estonian with Livonian, the Livonian form should be considered primary, also outside of texts specifically connected with Livonian subject matter. In addition, Estonian (and also Finnish) should follow Livonian practice with respect to the use of external locative cases with these place names (i.e., li Irēel $\sim$ ee Irēel $\sim f i$ Irēllä (AllSg) and li Pizās, ee Pizās, fi Pizāssa (IneSg)).

\section{Opportunities for preserving and restoring the Livonian place name landscape}

Despite the fact that the total number of Livonian speakers is now very small, Livonian community life is only becoming more active with each passing year and interest in Livonian heritage continues to increase across Latvia as a whole, but especially in the territories historically inhabited by Livonians. Along with this, interest in Livonian place name heritage and its use for regional development as well as the emphasis local uniqueness also continues to increase. At the same time, collecting place names and conducting related research is also important, for example, in creating publications in Livonian, publishing articles in periodicals, and communicating on social networks. 
In this context, the question of how Livonian is used in the linguistic landscape becomes topical. This use can entail a great meaning for the symbolic value of a language, be a fundamental component of identity, and hold prestige value for the community and society as a whole. Likewise, it can create an opportunity for influencing and supporting the vitality of a language and perhaps even the use of that language (Sallabank 2013: 163). Place names have an especially significant role here and their use on signage and in other visual elements can not only visually demarcate the region historically inhabited by Livonians, but can also serve as a carrier of identity in the territories historically inhabited by Livonians and for the modern Livonian community as well as promote greater interest in Livonian heritage as a whole.

\subsection{Official status and use of Livonian place names}

Compared to other endangered languages, Livonian is in a somewhat privileged position, as the legal status of Livonian place names and the rights to their use are specified in various Latvian national legal acts. Article 4 of the State Language Law ${ }^{1}$ expressly states that "The state guarantees the preservation, defence, and development of the Livonian language as an indigenous (autochthonous) language" and that Livonian can be used for place names as well as for the names of agencies, community organisations, businesses, and events, while the Regulations Regarding Geographical Names Information ${ }^{2}$ state that place names in the territories historically inhabited by Livonians are also to be in Livonian. However, the points specified in these legislative acts do not represent the actual use of Livonian in public spaces (up to this point, no official signage in Livonian has been posted anywhere).

Livonian place names were not used on public signage at any point up to the restoration of the independence of the Republic of Latvia. The first sporadic attempts at incorporating Livonian into the linguistic landscape took place in the first half of 1990 when signs were put up by motorways informing drivers that they were entering the Livonian cul-

Latvian State Language Law. Available online at $<$ https://likumi.lv/doc.php?id=14740>. Accessed on 26.05.2020.

2 Latvian Regulations Regarding Geographical Names Information. Available online at $<$ https://likumi.lv/ta/id/243610-vietvardu-informacijas-noteikumi $>$. Accessed on 26.05.2020. 
tural historical territory "Līvõd rānda" (The Livonian Coast; these signs have since disappeared). Since the 2000 s, place name use on signage has become more active; however, it has been carried out as part of private (businesses, residents of these territories) or community (nongovernmental organisation projects) initiatives.

At the end of 2018, an element of intangible cultural heritage the Livonian cultural space - was added to the Latvian National List of Intangible Cultural Heritage. While the application for adding the Livonian cultural space to this list was still being prepared, the Livonian Coast local governments (Ventspils municipality, Roja municipality, and Dundaga municipality) and community organisations had already agreed to cooperate on preserving and developing Livonian cultural historical heritage. They also agreed on its inclusion in the Latvian National List of Intangible Cultural Heritage and on its subsequent addition to the corresponding UNESCO list ${ }^{3}$.

Once the application was approved, placing Livonian-language signage in the territories historically inhabited by Livonians was agreed to be one of the most urgent and important tasks to be completed in order to visually demarcate the Livonian cultural space. At the end of 2018 and during 2019, the Dundaga municipal government in cooperation with other Livonian Coast local governments and the UL Livonian Institute compiled the information necessary for placing bilingual (Latvian and Livonian) road signs across the entire Livonian Coast territory, created sketches of these signs, and in early 2020 began their production. The new signs are expected to be put up in spring 2020.

However, the work associated with the planning and preparation for these signs revealed a number of problems associated with putting up official road signage. First of all, taking into account that official use of Livonian place names is an exception in Latvia - Livonian is the only other language which can appear alongside Latvian on official signage according to the law and there was no precedent for the use of such signage - the first problem to resolve was the lack of any standards for bilingual signs (these standards have now been established and are currently being harmonised with official institutions).

Livones.net. Available online at $<\mathrm{http}: / /$ www.livones.net/lv/norises/2018/?noslegtspirmais-sadarbibas-memorands $>$. Accessed on 26.05.2020. 
Another problem is associated with the contradictions and lack of clarity in the formulation of the regulations in the State Language Law and the Regulations Regarding Geographical Names Information. The State Language Law specifies that Livonian place names may be used on the Livonian Coast, which encompasses the region historically inhabited by Livonians in northern Courland, but is not an administrative territory. The Regulations Regarding Geographical Names Information, however, state that "names in the territories historically inhabited by the Livonians are to be created in Livonian"; this formulation describes a much larger area encompassing nearly one-third of the present-day Latvia. Therefore, lack of clarity concerning the area in which Livonian place names can be used on signage resulted in a delay in harmonising the associated regulations.

Another, perhaps a more fundamental problem connected with these laws as well as the actual process of collecting Livonian place names, is that the Regulations Regarding Geographical Names Information also state that "place names in the territories historically inhabited by the Livonians are to be created in Livonian according to its language norms". Thus, it can be concluded that the use of Livonian place names on official signage requires an official source for standardised Livonian place names. This type of source, however, currently does not exist and still needs to be created. One of the goals of the place name project initiated by the UL Livonian Institute this year is the creation of this type of information source.

\subsection{Expanding the Livonian place name landscape}

Putting up bilingual signage in historical Livonian territories and the possible future creation of a collection of Livonian sources means that in addition to the need to collect and standardise existing Livonian place names, but brand new Livonian place names also need to be created. Examples of these include names for tourist destinations in the Courland Livonian region - the Livonian Coast - which have been created since the restoration of Latvia's independence (the Antler Museum in Vaide (Sōrad muzej), the Kolka Livonian Meeting House (Kūolka līvõd $k u b k u o d \bar{a})$ ) as well as the Soviet-era military objects and inhabited localities such as Irbene, a military town located on the Livonian Coast, which is the site of the most well-known military landmark - 
nowadays used for scientific research - the Ventspils International Radio Astronomy Centre (one of the largest radio telescopes in Europe). Though some of these place names already have newly established Livonian forms, most of the work in creating such forms still lies ahead. Another important aspect of restoring and expanding the Livonian place name landscape is creating Livonian forms for other place names within Latvia, which is connected with the need to write about these places in Livonian. The issues associated with this have already been discussed to a certain extent in this article, namely, the grammatical features of Livonian place names and the process of representing Latvian place names in Livonian.

However, the most fundamental question is associated with those Latvian place names located in the territories historically inhabited by Livonians, which have no documented Livonian form, but which have entered Latvian from Livonian. In essence, this is a question of Livonian place names and language policy, which requires a choice between the technically simpler option - using Latvian place names and adapting them to the principles of Livonian place names and grammar - and, arguably, the more difficult option - reconstructing the Livonian forms of these place names and incorporating these names into Livonian language use.

\subsubsection{Creating Livonian place names with the help of reconstruction}

Examining the history of Livonian written language, it seems that there is no clear consistency in the forms used for place names located in those territories of Latvia that were historically inhabited by Livonians. For example, in the newspaper "Livvli", place names in Latvia were largely adapted from their Latvian form (Krustpil 'Krustpils' (Līvli 1932/3: 1); Kemer 'Kemeri' (Līvli 1932/4: 2)), although some place names in the historical Livonian territories did appear in a form phonetically adapted to Livonian (Ūogrõ 'Ogre' (Līvli 1932/2: 3)). This monthly paper does not contain many examples, as after Kārlis Ulmanis's 1934 coup d'état, all place names in Latvia - including those referring to the Livonian Coast villages - as well as other onyms (e.g., last names) were used in their Latvian form also in Livonian (Ernštreits 2013: 105; e.g., Mazirbe kyla instead of Irēe (Līvli 1935/7: 2)). 
An approach similar to early "Livvli" was taken by the compilers of the Livonian-Latvian-Esperanto Dictionary (ČCG). This source largely uses place names adapted to Livonian pronunciation and grammar (Sabīl Sābil 'Sabile', Kuldig 'Kuldīga', Siguld 'Sigulda', Krimuld 'Krimulda'), though some calques are also used (Kurē ouk 'Velnala (lit. Devil's cave)' = liC kuṛe 'devil'+ ouk 'cave') and historical reconstructions (Toraida 'Turaida', cf. Thoreida (BHO: 643)).

In the 1932 Livonian Calendar (RĀ 1932), however, there is extensive Livonianisation of Latvian place names, which focuses on the adaptation of place names to Livonian (Orisār 'Vecpiebalga', Pālo 'Pāle' (RĀ 1932: 34)), calquing (Rištnīn 'Krustpils (lit. cross castle)'= rišst 'cross'+ nin 'castle' (RĀ 1932: 58)), adapting place names to the etymology or possible semantics deducible from their historic forms (Siepakyla 'Pāle'= siepā 'smith' + kilā 'village' (RĀ 1932:43, 64), cf. Sepkull (BHO: 582)). The primary method, however, was creating the Livonian forms of place names according to the etymological interpretations of the editor of this publication, Laimonis Rudzitis (Ernštreits 2013: 109-110, 116) (Tārkyla 'Tārgale' (RĀ 1932:43, 64), cf. Targele (BHO: 640); Vendkyla 'Cēsis' = vend 'Vend' + kilā 'village' (RĀ 1932: 41), Pyvavež 'Puze' = pivā 'holy'+vež 'water' (RĀ 1932:64), Mecākyla 'Mēdzula' = mõts $\bar{a}$ 'forest' + kilā 'village', Liezjär 'Liezēre' and Lȳjjär 'Līdēre', cf. liS järu 'lake', Küja joug 'Kuja River' = kūja 'dry' + joug 'river' (RĀ 1932: 34)).

Though this kind of extensive Livonianisation of Latvian place names may seem excessive, it can still be concluded that there is a general historical trend to create Livonian forms of place names in territories historically inhabited by Livonians across all of Latvia, which takes into account the historical form of these place names, their possible etymological connections with Livonian, and opportunities for calquing. To some extent, this can also be seen in the LivonianEstonian-Latvian Dictionary (e.g., Piškisalāts 'Mazsalaca (lit. little Salaca)' = piški 'little' + Salāts 'Salaca'; Ikškilā 'Ikšḳile' = ikš 'one' + kilā 'village' (LELD)).

A recent noteworthy and successful example of place name Livonianization based on the possibilities offered by place name reconstruction can be seen in Ķempi Kārl's poetry collection "Salats joug kolm agga" (The Three Shores of the Salaca; Kempi 2013), which contains place name reconstructions in Salaca Livonian for places in the 
Vidzeme Livonian region (Korb 'Korbas', Pūrnau 'Pūrnava', Königkül 'Ķēniņciems (lit. king village)', Rank,ul 'Rankul̦i', Aggjoug 'Ag̀e River', Koijoug 'Gauja', Lēdūrg 'Lēdurga', Kulaūrg 'Kulaurga', Mustaūrg 'Melnupe (lit. black river)'; Ķempi 2013: 149-151).

Therefore, the aforementioned approach - creating new Livonian place names for the historical Livonian territories with the help of reconstruction - can be used for expanding the Livonian place name landscape. However, this should be done cautiously and only in cases where the creation of a Livonian form of a place name based on earlier forms is historically justified.

\subsubsection{Using calques for Livonian place name reconstruction}

One of the surest methods for restoring historical Livonian place names is using place names which have come into Latvian as calques from Livonian. The most well-known example of these in Courland is Lauciene ( $<$ lv lauks 'field') located near Talsi. The names of the Nurme Church ( $<$ liC nurm 'field'; cf. ee pn Nurme) and Nurmuiža ( $<$ liC nurm 'field' + moizõ 'manor (lv muiža)') have clear semantic parallels in Livonian. Here it is possible to reconstruct the Livonian place name Nurm $\sim$ Nurm kilā (lit. field village).

Calques can also be found across all of the regions of Vidzeme that were historically inhabited by Livonians. For example, in the historical Daugava Livonian region, there is a village near Ogre named Ciemupe $(<$ lv ciems 'village' + upe 'river'). The Kilupe River flows through it and its name contains a reference, it seems, to the original Livonian name (< liS k,ula $\sim$ liC kilā 'village'+ lv upe). When reconstructing Vidzeme Livonian place names in Livonian, the source for these should be the only recorded Vidzeme Livonian variety - the Salaca Livonian language. The reconstructed name of Ciemupe in Salaca Livonian would be Kulajoug $\sim$ Kuljoug, or possibly also as Kulaūrg $\sim$ Kulürg ( $<$ liS ürg 'stream').

In the historical Livonian region of Metsepole on the northern Vidzeme coast, there is a village named Liepupe $(<\operatorname{lv}$ liepa 'linden' + upe 'river'). Its German name Pernigel is apparently a shortened form of the earlier Pernigogel (1372) Perneyogel (1490; BHO: 461), which clearly shows its Livonian origins ( $<$ liS p pärn $\sim$ päern 'linden' + joug 'river'). The Livonian name of Liepupe in Vidzeme Livonian (liS) could be reconstructed as Pärnjoug Pärnjougel (cf. also ee Pärnjõe). 
In the historical Gauja Livonian region near Krimulda one finds Lake Jêrkule (also Lake Erkule and Lake Ierkule; < liS järu $\sim$ liC jōra 'lake' + liS k,ula liC kilā 'village'; cf. ee pn Järveküla), which takes its name from a nearby historically inhabited locality, as evidenced by the semantics of its name (i.e., Ezerciema ezers (lit. lake-village lake)). Signs that this place existed can be seen in the name of a place less than two kilometres to the north - Ezerciema skola $(<\mathrm{lv}$ ezers 'lake' + ciems 'village' (lv skola 'school'); currently uninhabited), which was called Jêrkules skola before. Using Salaca Livonian language data, this place name could be reconstructed as Järukula $\sim$ Järķula $\sim$ Järķul.

As can be seen in this and the previous section, the reconstruction of historical Livonian place names is one of the best options for restoring and expanding the Livonian place name landscape. In addition, as far as it applies to the territories historically inhabited by Livonians across all of Latvia, this would also be the most desirable method for restoring the Livonian place name landscape. Especially, considering the possible future interest in opportunities specified in legislation for including Livonian place names on signs across all of the historical Livonian language speech area, not just in northern Courland.

\section{Conclusion}

Knowledge of Livonian place names is sparse and they remain understudied; however, Livonian place names also constitute an exciting topic of study holding vast potential. The documentation and use of Livonian linguistic heritage, including place names, offers significant opportunities not only for the study of place names and other fields, but also for the preservation of cultural diversity and other values across the northern Baltic Sea region as well as for businesses and the tourism industry in the territories historically inhabited by Livonians.

Even though there are very few Livonian language speakers left and the use of fieldwork for documenting Livonian place names is no longer possible, applying innovative methods to existing sources makes it possible to not only successfully collect Livonian place names, but also link them to geospatial information, so that in the future - specifically thanks to mapped place names - there will be the potential to create new types and a new level of Livonian research and popularisation tools. 
Livonian place name research can also contribute to a better understanding of the Livonian language and its grammar as well as assist in reconstructing Livonian place names in the territories historically inhabited by Livonians across all of Latvia. This not only enriches Livonian itself, but also the linguistic landscape of the historical Livonian language speech area.

\title{
Acknowledgements
}

This study was supported by the Latvian Council of Science Fundamental and Applied Research Programme project "Documenting and mapping Livonian place names and creating an official place name register" (LZP-2019/1-0240).

\author{
Address: \\ Valts Ernštreits \\ Livonian Institute \\ University of Latvia \\ Kronvalda 4-220 \\ Rīga, LV-1010 \\ E-mail: valts.ernstreits@lu.lv
}

\begin{abstract}
Abbreviations
AblSg - ablative singular, AllSg - allative singular, ee - Estonian, IneSg - inessive singular, li - Livonian, liC - Courland Livonian, liE - Eastern dialect of Courland Livonian, liS - Salaca Livonian, liW - Western dialect of Courland Livonian, lv - Latvian, pn - place name
\end{abstract}

\section{References}

$\mathrm{BHO}=$ Baltisches historisches Ortslexikon. II, Lettland (Südlivland und Kurland). Hans Feldmann und Heinz von zur Mühlen, Hrsg. (Quellen und Studien zur baltischen Geschichte 8, II.) Köln and Wien: Böhlau Verlag, 1990.

Blumberga, Renāte, Tapio Mekeleinens, and Karls Pajusalu (2013) Lībieši. Vēsture, valoda un kultūra. Compiled and edited by Renāte Blumberga, Tapio Mäkeläinen, and Karl Pajusalu. Rīga: Līvõ Kultūr sidām. 
Boiko, Kersti (1990) "Fizioǵeogrāfiskie apelatīvi Ziemeḷkurzemes lībiešu zvejniekciemu vietvārdos”. In Benita Laumane, Dzintra Hirša, and Ojārs Bušs, eds. Onomastica Lettica, 52-85. Rīga: Zinātne.

Boiko, Kersti (1993) Baltijas jūras somu geoogrāfiskie apelatīvi un to relikti Latvijas vietvārdos. Unpublished linguistics doctoral degree dissertation. Rīga: Latvijas Zinātņu akadēmija, Latviešu valodas institūts.

Boiko, Kersti (1997) "Mõned läänemeresoome kohanimede areaalid Lätis”. In Õdagumeresoomõ lõunapiiŕ / Läänemeresoome lõunapiir / Itämerensuomen eteläraja, 20-31. (Võro Instituudi toimõtiseq, 1.) Võru: Võro Instituut.

$\check{C} \mathrm{DG}=$ Čače, Ints, Pēteris Dambergs, and Hilda Grīva (1966) Esperantisto en Latvio ĉe livoj. Unpublished manuscript. Pumpuri.

PDK $=$ Collection of Livonian place names by Pētõr Damberg.

Ernštreits, Valts (2013) Liivi kirjakeel. Tartu: Tartu Ülikooli kirjastus.

Ķempi, Kārl (2013) Salats joug kolm ağa. Salatsi jõe kolm kallast. Salacas upes trīs krasti. Mõtsāpūol: Līvõd sõbrād seḷtš.

LELD = Viitso, Tiit-Rein and Valts Ernštreits (2012) Līvõkīel-ēstikiel-lețkiel sõnārōntõz. Liivi-eesti-läti sõnaraamat. Lībiešu - igauñu - latviešu vārdnīca. Tartu: Tartu Ülikool; Rīga: Latviešu valodas aǵentūra.

Līvli = Līvli (1931-1939) [Monthly newspaper in Livonian]. Jelgava: Em. Štāler, Mazirbe: M. Stalte.

LL 1921 = Esimene Liivi lugemik. Kokkusäädnud Lauri Kettunen ja Oskar Loorits. Ežmi Līvəd lugdəbrōntəz. Sasādənd Prof. Lauri Kettunen un Štud. Oskar Loorits. (Akadeemilise Emakeele Seltsi toimetused, 1.) Tartu, 1921.

LL 1922 = Teine liivi lugemik. Toi līvad lugdabrōntaz. (Akadeemilise Emakeele Seltsi toimetused, 5.) Tartu, 1922.

LL 1923 = Kolmas liivi lugemik. Kolmaz līvad lugdabrōntaz. Sasädən August Skadiṇ. (Akadeemilise Emakeele Seltsi toimetused, 9.) Tartu, 1923.

LL 1924 = Neljas liivi lugemik. Nel'lõz līvõd lugdõbrōntõz. (Akadeemilise Emakeele Seltsi toimetused, 10.) Tartu, 1924.

LL 1926 = Viies liivi lugemik. Vìdõz līvõd lugdõbrōntõz. (Akadeemilise Emakeele Seltsi toimetused, 15.) Tartu, 1926.

Loorits, Oskar (1936) Volkslieder der Liven. (Õpetatud Eesti Seltsi toimetused, 28.) Tartu: Õpetatud Eesti Selts.

Loorits, Oskar (1998) Liivi rahva usund. Mit einem Referat: Der Volksglauben der Liven. I-III. [Facsimile]. (Õpetatud Eesti Seltsi toimetused.) Tartu: Eesti Kirjandusmuuseum.

Loorits, Oskar (2000) Liivi rahva usund IV-V. L. Krikmann, M. Hiiemäe, M. Kõiva, and K. Salve, eds. Tartu: Eesti Kirjandusmuuseum.

LR = Goba, Zinta, Jurğis Kavacs, and Otīlija Kovaḷevska (1993) Lìvõd rānda. Lìvu krasts. Vārdnīca. Unpublished cartographic material. LU ZPD G̣eogrāfijas nodaḷa. Rīga.

LVK = Latvijas Universitātes Latviešu valodas institūta vietvārdu kartotēka (University of Latvia Latvian Language Institute Place Name Card File). 
LW = Kettunen, Lauri (1938) Livisches Wörterbuch mit grammatischer Einleitung. (Lexica Societatis Fenno-Ugricae, 5.) Helsinki: Suomalais-ugrilainen seura.

RĀ 1932 = Rāndalist Ājgarāntoz 1933. äjgaston, kien at 365 pävvo. Rīgos: Līvod sõbrad seḷč Letmās, 1932.

RĀ 1933 = Lìvod Rāndalist Ājgarāntoz 1934. äjgaston, kien at 365 pävvo. Rīga: Līvod sõbrad seḷč Letmās, 1933.

Sallabank, Julia (2013) Attitudes to endangered languages: identities and policies. Cambridge University Press. https://doi.org/10.1017/CBO9781139344166

Setälä, Eemil Nestor (1953) Näytteitä liivin kielestä. Suom. ja julkaissut Väinö Kyrölä. Helsinki: Suomalais-ugrilainen seura.

Sīlis, Edgars (1996) “'Lībiešu krastam’ 5 gadi”. In Latvijas vēstnesis 27, 14.02.1996. Available online at $<$ https://www.vestnesis.lv/ta/id/38932>. Accessed on 26.02.2020.

$\mathrm{SjW}=$ Wiedemann, Ferdinand Johann (1861) Joh. Andreas Sjögren's Livisch-deutsches und deutsch-livisches Wörterbuch. (Joh. Andreas Sjögren's Gesammelte Schriften, Band II, Theil II.) St. Petersburg.

SLW = Winkler, Eberhard and Karl Pajusalu (2009) Salis-livisches Wörterbuch. (Linguistica Uralica. Supplementary Series, 3.) Tallinn: Teaduste Akadeemia Kirjastus.

Kokkuvõte. Valts Ernštreits: Kohanimed liivi keeles: kogumine, uurimine, probleemid ja võimalused. Liivi keel on üks ohustatumaid Euroopa keeli. Liivi päritoluga kohanimesid leidub mitte ainult kohtades, kus veel hiljuti on räägitud liivi keelt, vaid ka kõikjal liivi ajalooliselt asustatud aladel Lätis. Liivikeelsete kohanimede kogumine on siiski olnud fragmentaarne ja enamjaolt tehtud muude uurimistööde (nt üldise sõnavara kogumise, etnograafiliste ekspeditsioonide jms) kõrvalt. Liivikeelsete kohanimede dokumenterimine välitööde käigus enam pole võimalik, kuna liivi keelejuhte on jäänud väga vähe ja nende kohanimede tundmine on ajaloolistel põhjustel vaid väga üldine. Käesolev artikkel annab ülevaate eelnevast tööst liivikeelsete kohanimede dokumenteerimise alal, kohanimede grammatilistest iseärasustest, samuti vaatleb võtteid, mida saab kasutada liivikeelsete kohanimede kogumiseks, sh innovatiivselt lähenedes olemasolevatele andmekogudele ja kogudes kohanimesid nende metaandmetest, käsitleb liivikeelsete kohanimede loomise ja rekonstrueerimise vajadust ja võimalusi, selgitab vajadust ametliku liivikeelsete kohanimede allika järele ametlike viitade paigaldamiseks liivi areaali visuaalseks märgistamiseks ja liivikeelse kohanimede maastiku taastamiseks.

Märksõnad: kohanimed, onomastika, keelemaastik, keele staatus, liivi keel 